\title{
The Implication of Visa-Free Policy for Foreign Labors in Indonesia: Legal and Economic Impacts
}

\author{
Ruth Caroline R.A. Silalahi \\ Faculty of Law, Doctoral Program, Universitas Borobudur, Jakarta, Indonesia \\ Email: ruthcras@gmail.com
}

\begin{abstract}
Globalization does not only cause a rapid rotation of investment and information, but it also affects labor issues. In discontinue economic rollout and continue the economic development, the most important foundation that has to be highlighted is that all efforts must be based on the capabilities of the Indonesians themselves. Nevertheless, the principle should not arise in order to manipulate a capitals, technology and skills that came from abroad, as long as totally devoted to the interests of the people's themselves, without resulting in overseas dependency. For that reason, Indonesia does not give a boundaries for the presence of foreign parties either in the form of capital or as a professional worker that will involve in Indonesia economics. The issues in this research are; How does the visa-free grant policy for foreign citizens on the emergence of illegal labor under Presidential Regulation No. 21 of 2016 on Visa Free, and how the government should take steps to protect local workers from illegal foreign labor. The result of this study is, the government should anticipate the impact of labors freedom, especially the use of Tenaga Kerja Asing (Foreign Labors), the government should make regulations to supervised foreign labors.
\end{abstract}

Keywords-Visa-Free; Foreign Labors

\section{INTRODUCTION}

On present day, the worldwide labor is leaving their country for work missions abroad because it offer higher wages. The labor with high quality will certainly have a great chance to achieving higher salary. Globalization does not only cause a rapid rotation of investment and information, but it also affect labor issues. This kind of condition, not just on present day, but since long time ago, even though the migration flows from Indonesia has not been as fast as it is today. Since 1958, Indonesia established laws to govern the placement of foreign labors inside the country. In accordance with the juridical provisions of Article 28 Paragraph 1 and 89 of the Undang Undang Dasar Sementara 1950 (temporary law 1950) to guarantee a decent nation for Indonesia's employment, it is necessary to establish regulations to supervise the use of foreign workers in Indonesia.

The specific provisions to govern foreign labors after Indonesia independence is stated in Undang-Undang Nomor 3 Tahun 1958 Tentang Penempatan Tenaga Asing (Law Number 3 of 1958 concerning Foreign Labor Placement) or Undang-undang tentang Penempatan Tenaga Kerja Asing (Law on Foreign Labor Placement. Undang-undang Nomor 3 Tahun 1958 Tentang Penempatan Tenaga Asing (Law Number 3 of 1958 concerning Foreign Labor Placement), basically provide the widest possible opportunity for Indonesian labors to occupy positions in all fields of job, but the other problem is the limited human resources, it is still possible or permissible for foreign labors to occupy certain positions and work in Indonesia, but foreign labors with permission to work in Indonesia must be limited and supervised, thus the use of a supervisory institution with licensing instruments becomes the identity of Undang-undang Nomor 3 Tahun 1958 Tentang Penempatan Tenaga Asing (Law Number 3 of 1958 concerning Foreign Labor Placement), in which the licensing procedures involves several agencies.

Thus, in relation to employment law within the period after independence until 2005, several changes have been made, the process is based on consideration of the needs and social dynamics described above, the law that describe issue above is; Undang-undang Nomor 14 Tahun 1969 Tentang Ketentuan-Ketentuan Pokok Mengenai Tenaga Kerja (Law Number 14 of 1969 concerning Basic Provisions Regarding Labor); then Undang-undang Nomor 25 Tahun 1997 Tentang Ketenagakerjaan (Law Number 25 of 1997 concerning Manpower) and Undang-undang Nomor 11 Tahun 1998 Tentang Perubahan Berlakunya Undang-undang Nomor 25 Tahun 1997 Tentang Ketenagakerjaan (Law Number 11 of 1998 concerning Amendments to the Enactment of Law Number 25 of 1997 concerning Manpower) and another one is Undangundang Nomor 28 Tentang Penetapan Peraturan Pemerintah Pengganti Undang-undang Nomor 3 Tahun 2000 Tentang Perubahan Undang-undang Nomor 11 Tahun 1998 Tentang Perubahan Berlakunya Undangundang Nomor 25 Tahun 1997 Tentang Ketenagakerjaan Menjadi Undang-undang (Law Number 28 concerning the Stipulation of Government Regulation in Lieu of Law Number 3 of 2000 concerning Amendment to Law Number 11 of 1998 concerning Amendments to the Applicability of Law Number 25 of 1997 concerning Manpower into Law), the last one is Undang-undang 
Nomor 13 Tahun 2003 Tentang Ketenagakerjaan (Law Number 13 of 2003 concerning Manpower).

Inside the law of employment there has been a very fundamental change regarding the regulation of labor, specifically with regard to the arrangement of foreign labor whose development is not separately regulated as contained in Undang-undang Nomor 3 Tahun 1958 tentang Penempatan Tenaga Asing (Law Number 3 of 1958 concerning Foreign Workers Placement). However, in various changes to the labor law, the substance of the law is still maintained in relation to licensing institutions and the supervision and legal substance relating to the use and placement of foreign labor which are carried out by different institutions, so this is a good coordination. Among these institutions, such as Immigration, Prosecutors, Police, Badan Intelegen Negara (BIN) or State Intelligence Agency and Local Government.

In discontinue economic rollout and continue the economic development, the most important foundation that has to be highlighted is that all efforts must be based on the capabilities of the Indonesians themselves. Nevertheless, the principle should not arise in order to manipulate a capitals, technology and skills that came from abroad, as long as totally devoted to the interests of the people's themselves, without resulting in overseas dependency. For that reason, Indonesia does not give a boundaries for the presence of foreign parties either in the form of capital or as a professional worker that will involve in Indonesia economics.

In 1992, a immigration law was establish, Undang-Undang Nomor 9 Tahun 1992 (Law Number 9 Year 1992) which was later replaced by Undang-Undang Nomor 6 Tahun 2011(Law Number 6 Year 2011) as the most recent Act on Immigration. Undang-Undang Nomor 6 Tahun 2011 (Law Number 6 Year 2011) Article 1 Number (1) stated: "Keimigrasian adalah hal ihwal lalu lintas orang yang masuk atau keluar wilayah Indonesia serta pengawasannya dalam rangka menjaga tegaknya kedaulatan negara. Untuk menjamin kemanfaatan dan melindungi berbagai kepentingan nasional serta dalam rangka menegakkan kedaulatan negara di bidang keimigrasian maka perlu ditetapkan prinsip, tata pengawasan, tata pelayanan atas masuk dan keluarnya orang ke dan dari wilayah Indonesia sesuai dengan nilainilai dan tujuan nasional Negara Republik Indonesia yang berdasarkan Pancasila dan Undang-Undang Dasar 1945. "(Immigration is the matter of people traffic entering or leaving the territory of Indonesia and their supervision in order to maintain the upholding of the country's sovereignty. In order to guarantee the usefulness and protect various national interests and in the context of upholding state sovereignty in the field of immigration, it is necessary to stipulate principles, governance, service for the entry and exit of people to and from Indonesian territory in accordance with the national values and objectives of the Republic of Indonesia based on Pancasila and 1945 Law.)

Every foreigner who will enter Indonesia must have a visa or permit to enter Indonesia except for those whose countries are exempt from the obligation to hold a visa. Definition of Visa is set in Undang-Undang Nomor 6 Tahun 2011 Pasal 1 Angka (18) (Law Number 6 of 2011 Article 1 Number (18) ) that stated "Visa Republik Indonesia yang selanjutnya disebut Visa adalah keterangan tertulis yang diberikan oleh pejabat yang berwenang di Perwakilan Republik Indonesia atau di tempat lain yang ditetapkan oleh Pemerintah Republik Indonesia yang memuat persetujuan bagi Orang Asing untuk melakukan perjalanan ke Wilayah Indonesia dan menjadi dasar untuk pemberian Izin Tinggal." (Visa in Republic of Indonesia, referred as Visa, is a written statement given by an authorized official in the Republic of Indonesia Representative or at another place determined by the Government of the Republic of Indonesia which contains approval for Foreigners to travel to the Territory of Indonesia and become the basis for granting Stay Permit) Types of Visa:

1. Visa Diplomatik (Diplomatic Visa)

2. Visa Dinas (Service Visa)

3. Visa Kunjungan (Visit Visa)

4. Visa Tinggal Terbatas (Limited Residence Visa)

The Government give a Free Visit Visa to 45 Countries based on the Presidential Regulation Number 69 of 2015 which was opened since June 10, 2015. The regulation was 100 days later, precisely on September 18, 2015, based on Presidential Regulation Number 104 of 2015 issued. The number of countries that have free visit visa to Indonesia has increased to 90 countries. The Government's breakthrough to provide visa-free visits to 169 countries, in accordance with Presidential Regulation No. 21 of 2016 concerning Free Visit Visa and Minister of Law and Human Rights Regulation No. 17 of 2016 concerning Specific Immigration Checkpoints, Conditions, and Arrival Destinations For Foreigners Who Get Free Visit Visa, has had a negative impact on Indonesia. The case of the increasing number of drugs entering the Negara Kesatuan Republik Indonesia (NKRI) or Republic of Indonesia by all means and the entry of tens or hundreds or thousands of labors from China, are two examples of cases which are one of the main causes due to the free visit visa policy to 169 countries.

Actually the government also regulates the activity that foreigners receiving Free Visit Visa can carry out activities for tourist purposes, family visits, social, arts and culture, government duties, giving lectures or attending seminars, attending international exhibitions, attending office meetings central or representative in Indonesia, and to continue traveling abroad.

The problem is that foreigners make use of the free visa that is not accordance with the original purpose for activities that have been mention above, but there are also foreigners who use it as job behalf but they are only apply for tourist visa. Based on this issue, the writer is interest to research and appointed a scientific work with the title "THE IMPLICATION OF VISA-FREE FOR FOREIGN LABORS IN INDONESIA: LEGAL AND ECONOMIC IMPACTS",

Based on what has been described above, the main issues in this study are as follows: (1) What is the impact of the policy of giving visa-free for foreigners to 
the emergence of illegal foreign labor based on Presidential Regulation Number 21 of 2016 concerning Visa-Free? And (2) what is the next steps for the government to protect local labor from illegal foreign labor?

\section{RESEARCH METHOD}

This paper includes normative research which is also often referred to as doctrinal research with the object or target of research in the form of regulations, legislation and other legal materials (Mudzakir, p.14). The result of legal research, although not inventing new legal theories, it is at least in the form of new arguments (Marzuki, 2005). This research conducted an normative juridical that is by examining the subject matter as mentioned above. In addition, this research will also complement from other relevant aspects based on the scope and identification of the problem formulated. Research on Legal Problems of Foreign Labor in Indonesia will be conducted by conducting library research and empirical research. In empirical research primary data will be produced, and from library research will be obtained secondary data which will be obtained from descriptions of how the laws and regulations governing foreign labor are applied in the field.

\section{RESULT AND DISCUSSION}

A. The Impact of free visa policy for foreign labors for the emergence illegal labor based on PP No 21 Year 2016 about Free Visa

The policy of granting a visa-free visit is based on the Presidential Regulation Number 21 of 2016 concerning Visit Visa Free in Article 2 as follows:

(1) Bebas Visa kunjungan diberikan kepada Penerima Bebas Visa Kunjungan dengan memperhatikan asas timbal balik dan asas manfaat. (Visit visa free is given to recipients of a Visit Visa Free by paying attention to the principle of reciprocity and the principle of benefit.)

(2) Bebas Visa kunjungan tidak diberikan, atas kunjungan dalam rangka jurnalistik. berdasarkan Peraturan Presiden Nomor 21 Tahun 2016 tentang Bebas Visa Kunjungan. (visit visa free is not given, for visits in journalistic terms. based on Presidential Regulation Number 21 of 2016 concerning Visit Visa Free.)

Pasal 3 (Article 3):

(1) Penerima Bebas Visa Kunjungan dibebaskan dari kewajiban memiliki Visa kunjungan untuk masuk wilayah Indonesia. (Recipients of a Visit Visa Free are exempted from the obligation to have a Visit Visa to enter Indonesian territory.)

(2) Penerima Bebas Visa Kunjungan sebagaimana dimaksud pada ayat (1) dapat masuk ke Wilayah Indonesia melalui Tempat Pemeriksaan Imigrasi tertentu. (Visit Visa-Free Recipients as referred to in paragraph (1) may enter the Indonesian Territory through certain Immigration Checkpoints
(3) Daftar negara, pemerintah wilayah administratif khusus suatu negara, dan entitas tertentu yang menerima Bebas Visa kunjungan tercantum dalam Lampiran yang merupakan bagian tidak terpisahkan dari Peraturan Presiden RI. (The list of countries, the government of a particular administrative area of a country, and certain entities that receive a Visit Visa Free are listed in the Annex which is an integral part of the Indonesian Presidential Regulation.)

In Pasal 4 stated that:

(1) Penerima Bebas Visa Kunjungan sebagaimana dimaksud dalam Pasal 3 diberikan izin tinggal kunjungan untuk waktu paling lama 30 (tiga puluh) hari. (The Visit Visa Free recipient as referred to in Article 3 is granted a residence permit for a maximum period of 30 (thirty) days.)

(2) Izin tinggal kunjungan sebagaimana dimaksud pada ayat (1) tidak dapat diperpanjang masa berlakunya atau dialihstatuskan menjadi izin tinggal lainnya. (Stay permit visit as referred to in paragraph (1) cannot be extended for the validity period or transferred to another residence permit.)

Pasal 5 stated that:

(1) Ketentuan mengenai tata cara masuk dan keluar Wilayah Indonesia dan tujuan kedatangan bagi Penerima Bebas Visa Kunjungan diatur dengan Peraturan Menteri. (Provisions regarding the procedures for entering and exiting the Indonesian Territory and the purpose of arrival for recipients of Visit Visa Free are regulated by a Ministerial Regulation.)

(2) Ketentuan mengenai Tempat Pemcriksaan imigrasi tertentu sebagaimana dimaksud dalam Pasal 3 ayat (2) ditetapkan dengan Peraturan Menteri. (Provisions concerning certain immigration Check Points as referred to in Article 3 paragraph (2) are stipulated by a Ministerial Regulation.)

Pasal 6: "Dalam keadaan tertentu yang berkaitan dengan keamanan negara dan kesehatan masyarakat, Menteri dapat menghentikan sementara bebas Visa kunjungan untuk negara, pemerintah wilayah administratif khusus suatu negara, dan entitas tertentu sebagaimana dimaksud dalam Pasal 3 ayat (3)".(In certain circumstances relating to state security and public health, the Minister may temporarily suspend the visit visa for the state, the government of a special administrative territory of a country, and certain entities as referred to in Article 3 paragraph (3) (In certain circumstances relating to state security and public health, the Minister may temporarily suspend the visit visa for the state, the government of a special administrative territory of a country, and certain entities as referred to in Article 3 paragraph (3) )

Increasing the collaboration between nations can make sophisticated technological advancements that can led to an increasing in the flow of human traffic between countries. Indonesian itself needs relations with abroad, which is in the form of investment, technology and expertise. In addition, Indonesia also needs an overseas market to market its products, both oil and gas and non-oil and gas. 
The demands of development led to an increasing the flow of human traffic from and out of Indonesia territory. "In order to guarantee the benefit and protect the various national interests, it is necessary to regulate the principles, procedures for supervision, service arrangements for the entry and exit of people to and from the territory of Indonesia in accordance with the national values and objectives of the Republic of Indonesia based on Pancasila and the Undang - Undang Dasar 1945 ".

The law enforcement function is to carry out and enforcing the law for everyone who involve in law activities that are contrary to applicable law, such as the guarantor's responsibility, falsification of identity and violation of immigration rules.

The implementation of mechanism for granting residence permits is given by immigration officials at the Immigration Checkpoint according to the visit visa issued by Indonesia representatives abroad and only allow to stay in Indonesia for a maximum of 60 days. The stay permit for the visit can be extended for a maximum of 4 (four) times and the period of each extension is not more than 30 days. The issue of a stay permit extension, the application file is submitted to the Immigration Office whose working area covers the residence of a foreigner, enclosing the requirements, namely a guarantee letter from the guarantor when applying for a visa and a valid passport. The law enforcer will receive and examine the guarantee letter by matching the guarantor listed on the visa in the foreigner's passport. In fact, the research process will arise two problems, namely:

1. Visit visa that does not include the name of the guarantor.

2. Visit visa includes the name of the guarantor, but the guarantee letter is signed by the party not included in the visit visa.

The established of Presidential Regulation No. 21 of 2016 concerning Free Visit Visa, there are several principles that regulate it so that its implementers have a positive impact. One of them is the principle of proportionality in the implementation of the immigration function, and one of the functions is the law enforcement function where the entire rule of law must be upheld consistently, and decisively.

Warga Negara Asing (WNA) who enter Indonesia generally use BVKS facilities or using a tourist visa that will get a residence permit in accordance with the visa entry visa and free visa. Within the residence permit the visit will be explain that the visit permit was used for tourism which misused for other purposes, namely for working.

a. Visa On Arrival, that cause the possibility of misuse of this Residence Permit are:

- The opportunities for Visa On Arrival are not much different from Visit Visa because of a 1 (one) maximum extension, then after expiration of the Stay Permit in Indonesia, the foreigner should get out from Indonesia and returns on the same day so that they can enter again by buying a Visa at the Immigration Checkpoint when they arrive and get a Stay Permit for another 30 days and can renew 1 (one) time.

- Very cheap prices for purchasing Visa On Arrival itself so that the opportunity for foreigners to get the ease or opportunity to get a job in Indonesia.

b. Bebas Visa Kunjungan Singkat (BVKS) or Free Visa for Short Visit

The things that cause the possibility of misuse of this Residence Permit are due to the ease of Free Visa granted to 15 (fifteen) countries, because they are considered not to incur costs and the time is given 1 (one) month or 30 days to be able to visit Indonesia with tourist destinations, the task of government so as to make opportunities for foreigners who will work in Indonesia using the Residence Permit.

B. The Impact of free visa policy for foreign labors for the emergence illegal labor based on PP No 21 Year 2016 about Free Visa

According to the data, workers included in plantations, gold mines, coal, rubber workers, which were 21,000 in all of Indonesia. In city factories, especially in Kalimantan, all Chinese labour are employed. Meanwhile, apart from the number of foreign labor from China in the field, the real problem lies in the supervision of permits that are considered insufficient. According to legislation in Indonesia, those who are allowed to enter are only for those whose positions cannot be filled by local workers. Almost the majority (Chinese foreign workers who enter) do not fulfill licensing, because those who want to invade Indonesia are abusive laborers, and there is no room in any (trade) agreement.

From the data found, it includes the position of experts, such as mechanical engineering or quality control managers, but in reality the position carried out by illegal foreign workers from China is not in accordance with what is stated. Even also found illegal foreign workers who did not have work permits at all. And to concerns about the possibility of the existence of foreign workers in seizing employment for Indonesian citizens. Ministry of Manpower and Transmigration record the number of foreign labor in Indonesia on November 2016-2017 was 74,183 people. And China, with 21,271 workers, is the most sending country to Indonesia, and Japan is in second place with 12,490 workers. They are mostly distributed in the trade and services sector.

This act cause elimination of employment opportunities for local labor. So far the government has a scheme to control the entry of foreign labor into Indonesia. Thus, no foreign labor can work in Indonesia. "Firstly, the government has a clear control scheme for foreign workers in Indonesia. Whereas those who can enter and work in Indonesia are only those who are skilled. Not all positions are occupied by foreign labor. So only certain positions are essentially skill and professional. Indonesia is not a country that is closed to foreign parties, including from the side of its workforce.Therefore, it is natural that there are Chinese workers or foreign workers working in Indonesia. Secondly, Indonesia is an open country, so the entry of 
foreign labor must be seen as the dynamics of globalization. As long as foreign labor enter and work in Indonesia in accordance with applicable regulations, there will be no problem.

The steps that should be taken by the government to protect local workers from the invasion of foreign workers are as follows:

(1) To anticipate the impact of labor freedom, especially the use of Tenaga Kerja Asing (TKA) or Foreign Labor, the government must make laws and regulations governing the supervision of Tenaga Kerja Asing (TKA) or Foreign Labor. The role of the government to protect local labor from the invasion of foreign labor.

(2) Develop supervision for Tenaga Kerja Asing (TKA) or Foreign Labor.

(3) Supervision of Tenaga Kerja Asing (TKA) or Foreign Labor can be in the form of Izin Mempekerjakan Tenaga Kerja Asing(IMTA) or Permits for Employing Foreign Workers for each Tenaga Kerja Asing (TKA) or Foreign Labor used by the company concerned, examining the type of work or position and examining the presence or absence of accompanying workers.

(4) Improve local labor skills.

\section{CONCLUSION}

It can be concluded that the impact of the policy of granting free visa for foreign nationals to the emergence of Illegal Foreign Workers Under Presidential Regulation No. 21 of 2016 concerning Visit Visa Free has a positive and negative impact. The positive impact is first Pendapatan Asli Daerah (PAD) or Regional Income of the city / regency, which comes from local taxes and retribution. The next impact is the transfer of science and technology. Then the negative impact is the reduced opportunity for Local Workers, this section will be divided into the Role of the Government in the Province in overcoming the number of unemployed due to the existence of Foreign
Labor. The steps that should be taken by the government to protect local workers is to anticipate the impact of freedom in the world of labor, especially the use of Tenaga Kerja Asing (TKA) or Foreign Labor, the government must make legislation governing the supervision of Tenaga Kerja Asing (TKA) or Foreign Labor. The role of the government to protect local workers by examining the type of work or position and examining the presence or absence of counterpart workers.

\section{REFERENCE}

[1] Abdullah Syaiful James, Memperkenalkan Hukum Keimigrasian, Jakarta: Ghalia, 1993.

[2] --- Komentar Atas Undang-Undang Nomor 9 Tahun 1992 tentang Keimigrasian, Jakarta: Ghalia Indonesia, 1992.

[3] Apeldooorn, Van, Pengantar Ilmu Hukum, Jakarta: PT Pradnya Paramita, 1985.

[4] AHD. Nasir Hia, "Tinjauan Hukum terhadap Birokrasi Pengurusan Paspor Berbasis Biometrik di Kantor Imigrasi Polonia Medan', Tesis, Medan: Sekolah Pascasarjana USU, 2007.

[5] Bambang Sunggono, Metodologi Penelitian Hukum, Cetakan Ketiga, Jakarta: PT. Raja Grafindo Persada, 2003.

[6] Bagir Manan, Hukum Keimigrasian dalam Sistem Hukum Nasional, Jakarta: 2000.

[7] I Wayan Parthiana, Pengantar Hukum Internasional, Bandung: Mandar Maju, 1990.

[8] Kansil, C.S.T., Pengantar Ilmu Hukum dan Tata Hukum Indonesia, Jakarta: PN Balai Pustaka, 1982.

[9] Koemiatmanto Soetorawiro, Hukum Kewarganegaraan dan Keimigrasian Indonesia, Jakarta: Gramedia Pustaka Utama, 1996.

[10] M.Imam Santoso, Perspektif Imigrasi dalam Pembangunan Ekonomi dan Ketahanan Nasional, Jakarta: UI Press, 2004.

[11] Muhammad Indra, "Perspektif Penegakan Hukum dalam Sistem Keimigrasian Indonesia, Disertasi, Progam Doktor Program Pascasarjana, Bandung: Universitas Padjadjaran, 2008.

[12] Mertokusumo Adikun Sudikun, Mengenal Hukum Keimigrasian, Jakarta: Liberty, 1991 